\title{
LABIRINTO EM CAMILO PESSANHA: ÁGUA EM IMAGENS
}

\section{LABYRINTH IN CAMILO PESSANHA: WATER IN IMAGES}

\author{
Antônio Roberto Giraldes ${ }^{1}$
}

\begin{abstract}
Resumo: Partindo da noção simbólica do "Labirinto", iluminando-o, paradoxalmente, com a escura luz do mistério, vislumbra-se muito mais que algo sem saída, vislumbra-se algo que oferece caminhos tortuosos e intrincados para um possível encontro transcendente no centro de nós mesmos. Dessa forma, a agonia labiríntica sentida no "estar-se perdido" estimula um movimento aO Regime Noturno da Imagem (DURAND) como forma de enfrentamento simbólico à angústia existencial (MORIN). O presente trabalho perpassará pelos Labirintos do poeta Simbolista português Camilo Pessanha, na obra Clepsidra, singrando por alguns poemas, tendo como companhia de navegação as águas e os sonhos de Gaston Bachelard.
\end{abstract}

Palavras-chave: Imaginário, Literatura, Labirinto, Devaneio.

\begin{abstract}
Departing from the symbolic notion of the "Labyrinth", illuminating it, paradoxically, with the dark light of mystery, one glimpses more than something with no way out, one glimpses something that offers tortuous and intricate paths for a possible transcendent encounter in the center from ourselves. Thus, the labyrinthine agony felt stimulates a movement to the Night Image Regime (DURAND) as a symbolic confrontation with existential anguish (MORIN). The present work will pass, sideways, through the Labyrinths of the Portuguese symbolist poet Camilo Pessanha, in the work Clepsidra, sailing for some poems, having as a navigation company the waters and dreams of Gaston Bachelard.
\end{abstract}

Keywords: Imaginary, Literature, Labyrinth, Daydream.

Camilo Pessanha foi um poeta português do final do século XIX. Formou-se em Direito, viajou para Macau para trabalhar como professor. A viagem ao oriente trouxe-lhe contato com outro tipo de cultura e o vício do ópio. Retornou a Portugal por duas vezes para tratamento de saúde e das saudades da terra natal. Faleceu em 1926.

\footnotetext{
${ }^{1}$ Doutor em Educação pela Faculdade de Educação da Universidade de São Paulo.
} 
A Poesia Simbolista alicerça-se bastante na camada fônica e em como sua intensidade possibilita a transcendência da palavra no papel para a forma sonora reverberante pelo espaço, fazendo-se tocar nos corpos ao tocar nos tímpanos, pois, sendo o tímpano parte dos nossos corpos, o som do poema, com as imagens sinestésicas construídas, transforma o tímpano de algo pensado como reverberador de som como algo "tocado" pelo ar.

Esse deslumbramento do toque sonoro para o toque tátil, efetivamente corporal, nota-se isomorfo com outro princípio também muito utilizado: a sinestesia. Tal figura de palavra, na mistura de sensações, penetra na transcendência, naquele lugar labiríntico entre a cor e o paladar, o som e o toque, a alma e o corpo. Essa poesia-corpo remete-nos à base da imaginação material:

Expressando-nos filosoficamente desde já, poderíamos distinguir duas imaginações: uma imaginação que dá vida à causa formal e uma imaginação que dá a vida à causa material; ou, mais brevemente, a imaginação formal e a imaginação material. [...] É necessário que uma causa do coração se torne uma causa formal para que a obra tenha a variedade do verbo, a vida cambiante da luz. Mas além das imagens da forma, tantas vezes lembradas pelos psicólogos há [...] imagens da matéria, imagens diretas da matéria [...] Essas imagens da matéria, nós as sonhamos substancialmente, intimamente, afastando as formas, perecíveis, as vãs imagens, o devir das superfícies. Elas têm um peso, são um coração. (BACHELARD, 2002, p.13).

Em muitos momentos, não há a possibilidade de separar uma imaginação da outra, todavia, o aprofundamento em um poema mais denso, que singra atrás da ontologia das matérias em si, encontra imagens ocultas atrás das imagens iniciais. Opondo-se à imaginação formal, a imaginação material não se fixa na geometria lúdica das formas, mas segue ao corpo quase como exercício performativo de adentramento na matéria:

Água, ar, terra e fogo nos conduzem a realizar na poiésis, na elaboração da imagem, aquilo que a palavra isolada não dá conta e, dessa forma, gera um novo relacionamento com a matéria pela ação sublimadora, mantendo a tensão que lhe dá movimento, pois a análise dos movimentos é reveladora. (FERREIRA-SANTOS e ALMEIDA, 2012, p.36).

Não serão isso as sinestesias e aliterações, singrando o descompasso do poema?

É preciso que ele seja belo para ver o belo. É preciso que a íris do olho tenha uma bela cor para que as belas cores entrem em sua pupila. Sem um olho azul, 
como ver realmente o céu azul? Sem um olho negro, como contemplar a noite? Reciprocamente, toda a beleza é ocelada. (BACHELARD, 2002, p. 31).

A beleza seria retratada com vários ocelos, vários olhos pequenos, nuances que a colocam em movimento e nos colocam em movimento. A noção do belo segue-se como algo variegado ( $\underline{\pi 01 \kappa i ́ \lambda o s)}$, de difícil apreensão por conta das variações do objeto, nas cores, no caráter, no chamuscamento.

Chegamos a esse paradoxo: um acontecimento da história estética que não pode ser definido através de considerações estéticas. É preciso procurar em outro lugar o segrego de seu agrupamento. Tenho uma hipótese. Digo que nossos simbolistas, tão diferentes, estavam unidos por alguma negação, e essa negação era independente de seus temperamentos e de sua função de criadores. (VALERY, 2011, p. 66)

Negação dos valores, do requinte, do padrão; tarefa ingrata. Negar a direção objetiva e apolínea do olhar com sua percepção do distanciamento possibilitada pelo signo, por aquilo distante que aponto com o dedo (portento divino - $\sigma \eta \mu \varepsilon i ̃ o v)$. Tal negação propicia o impreciso, encontra olhos ocelados, olhos de dentro, do escuro, dos ouvidos e da matéria. Transpõe a percepção do signo para o símbolo.

O que chamamos símbolo é um termo, um nome ou mesmo uma imagem que nos pode ser familiar na vida diária, embora possua conotações especiais além do seu significado evidente e convencional. Implica alguma coisa vaga, desconhecida ou oculta para nós. (JUNG, 1964, p 20)

O vago, impreciso, oculto e diferente se predispõe ao movimento e ao encontro. Como o que desejo se encontra numa nuvem ou na confusão de um labirinto, necessito, nessa construção de entradas e saídas, do "outro", tal como Teseu precisa do fio de Ariadne.

Trata-se de passar às imagens que a vida não prepara e que o poeta cria. Tratase de viver o invivido e de se abrir para uma abertura da linguagem. A palavra poética não exprime nada anterior a ela, mas "trabalha" a realidade. Nem "linguagem-instrumento", nem "linguagem-sistema", a palavra poética não é significativa de um dado prévio, pois não nomeia nada daquilo que deveria ser efetivamente nomeado e que lhe pré-existia; é o "ser-novo", inseparável de sua efetivação, que é instituído pelo devaneio poético. O devaneio apresenta assim um caráter fundante, em virtude da originalidade dessa ultrapassagem. É a "criação" que dá significado à imagem poética, diferente da simples "metáfora". (FELICIO, 1994, p.49) 
Nessa criação efetiva, talvez o melhor de todos os poetas não tenha composto sequer um verso. A beleza criativa talvez esteja nos olhos de quem vê, ou melhor, no encontro dos olhares de todos (vários olhos - ocelos) - o mais belo do poema (poeta) talvez seja a interpretação dele.

O trabalho da leitura pode ser até mais intenso e material que o trabalho da produção do texto. No trabalho de leitura de um texto alheio, pode-se ganhar muito mais que no trabalho da escrita de um solitário escritor. Quanto mais pessoas no processo de imaginação do mundo, mais nos interligamos; mais ficamos de mãos dadas e mais nos tornamos humanos.

Convido-o, então, leitor, a ler comigo um dos poemas de Clepsidra de Camilo Pessanha:

Imagens que passais pela retina

Dos meus olhos, porque não vos fixais?

Que passais como a água cristalina

Por uma fonte para nunca mais!...

Ou para o lago escuro onde termina

Vosso curso, silente de juncais,

E o vago medo angustioso domina,

- Por que ides sem mim, não me levais?

Sem vós o que são os meus olhos abertos?

- O espelho inútil, meus olhos pagãos!

Aridez de sucessivos desertos...

Fica sequer, sombra das minhas mãos,

Flexão casual de meus dedos incertos,

- Estranha sombra em movimentos vãos.

(PESSANHA, 1989, p.41)

Um incauto pode perguntar-se: Onde está o Labirinto?

Esse mesmo incauto, com a pergunta, apercebe-se, de que já está dentro do labirinto. A imagem tradicional de uma construção na ilha de Creta transcende-se em outras imagens, tal 
como segue o rio baldio (Riobaldo) nas veredas labirínticas de nosso interior: "O sertão está em toda a parte!” (ROSA, 2001, p. 24), ou seja, o Labirinto está em toda a parte.

O movimento labiríntico que nos interessa é a água, a liquidez de nossos olhos perdendo-se no que eles veem e tocam: "as imagens passam pela retina e não a retina passa pelas imagens."

O olhar, dizíamos, envolve, apalpa, esposa as coisas visíveis. Como se estivesse com elas numa relação de harmonia preestabelecida, como se as soubesse antes de sabê-las, move-se à sua maneira em seu estilo sincopado e imperioso. No entanto, as vistas tomadas não são quaisquer, não olho um caos nas coisas, de sorte que não se pode dizer, enfim, se é ele ou se são elas quem comanda. (MERLEAU-PONTY, 1992, p. 130)

É esse apalpamento do olhar a referência sinestésica. No poema, o olhar sente-se impotente ao toque das imagens, que lhe fogem pelos olhos, seguem as mãos à cata do toque (na mistura sugerida entre o visual e o tátil), que também acaba por "ver com as mãos" a própria sombra do movimento delas.

As imagens "passam pela retina", não são apreensíveis, não se guarda uma imagem dentro do olho da mesma forma que não se guarda um voo de um pássaro dentro de uma gaiola (CÍCERO, 1996, p.11); o olho só se segue imagem quando em movimento, da mesma forma que a vida só pode ser vivida quando ela própria se esvai pelo tempo, a vela só se percebe viva quando se acende, sendo o acendimento o prenúncio de seu fim.

Basta que eu veja alguma coisa, para saber ir até ela e atingi-la, mesmo se não sei como isso se faz na máquina nervosa. Meu corpo móvel conta no mundo visível, faz parte dele, e é por isto que eu posso dirigi-lo no visível. Por outro lado, também é verdade que a visão pende do movimento. Só se vê aquilo que se olha. Que seria a visão sem nenhum movimento dos olhos, e como o movimento destes não haveria de baralhar as coisas se, por sua vez, fosse reflexo ou cego, se não tivesse suas antenas, sua clarividência, se a visão não se precedesse nele? (MERLEAU-PONTY, 1992, p. 278)

Segue a água cristalina para o lago escuro, segue o curso, o caminho rumo ao silêncio dos juncos, uma sensação de que o apego às coisas que vemos e que passam leva-nos ao escuro, todavia, permanecer-se fixo e sem movimento nos deixa apenas na forma da imaginação (imaginação formal): "Sem vós o que são os meus olhos abertos? / - O espelho inútil, meus olhos pagãos! / Aridez de sucessivos desertos...”. (PESSANHA, 1989, p.41) 
O grande enigma está em perceber que nossos movimentos não são somente apreensões de mundo, decisões de nosso espírito, fazeres absolutos, mas sim o amadurecimento de um olhar, olhar como um tecido nervoso que toca no objeto olhado, que se quase integra no objeto olhado. (GIRALDES, 2016, p. 48)

- Mas onde está o Labirinto? - reitera-se o incauto.

Naquele "lago escuro" onde termina o "curso das águas", no meio dos juncos, para onde vai toda a água corrente. $\mathrm{O}$ curso, curso esse conduzido pelos sons, pelos ouvidos.

Uma bela aliteração: "Vosso curso silente de juncais."

O silêncio silente sussurrante guiando-nos pelo escuro do lago. Basta, caro leitor, que você apague as luzes de seu quarto e, no meio do silêncio, seja guiado por sons constritivos surdos alveolares, seu fio de Ariadne, a conduzi-lo pelo labirinto do escuro rumo a um desconhecido interno e lunar. Labirinto de Sons. Labirinto de Vozes. O Labirinto está em toda a parte. O som sussurrante das águas escuras correntes nos guiando para onde fogem nossos olhos/imagens e mãos táteis/visuais.

Há que se caminhar para o centro de olhos fechados (lago escuro) guiado pelo som das palavras, permitir-se, perder-se. Acompanhando a água que escapa pelos dedos, que faz com que o olhar sobre o movimento dos dedos seja uma sombra vã daquele movimento incursivo da água sobre a escuridão.

$\mathrm{O}$ processo reside essencialmente em que pelo negativo se reconstitui o positivo, por uma negação ou por um ato negativo se destrói o efeito de uma primeira negatividade. Pode-se dizer que a fonte da inversão dialética reside neste processo da dupla negação, vivida no plano das imagens, antes de ser codificado pelo formalismo gramatical. Este processo constitui uma transmutação dos valores: eu ato o atador, mato a morte, utilizo as próprias armas do adversário. (DURAND, 2002, p.204)

Essa empatia pelo lago escuro (intrusão no $\pi \alpha ́ \theta 0 \varsigma$ - paixão) vista como caminho para a escuridão é característica dO Regime Noturno da Imagem. A escuridão é agonizante, dói, persigo então a totalidade dela própria a fim de negá-la duas vezes e terminar com a minha angústia, uma inversão da atitude representativa.

Mas, no poema, o curso das imagens líquidas vai e deixa sozinho o poeta "- Porque ides sem mim, não me levais!". O poeta sente, então, o "vago medo angustioso": "angústia" de não se conseguir chegar até a "angústia" para destruir a "angústia”. É verdade, caro leitor, um labirinto de espelhos. 
A angústia existencial, a entrega a ela pelas imagens mais profundas, parece absorver qualquer ser humano, mesmo o mais descrente, uma vez que ela, possivelmente estará em algo que ele "curte" ou acha belo:

O termo "angústia" é derivado do latim "angor" ou espanhol "angosto", passagem estreita que faz referência ao estreitamento vaginal quando a criança está em via de seu nascimento durante o parto. O não saber o que virá, o estreitamento crescente aumentando a pressão durante o processo, $o$ distanciamento cada vez maior da tranquilidade do líquido amniótico (simbolicamente o mar primeiro, "thalassal", como diria Sandor Ferenczi) no ventre materno. De maneira paradoxal, a angústia experimentada nos processos de transformação sempre conserva um renascimento. (FERREIRASANTOS e ALMEIDA, 2012, p.64).

A angústia existencial, por sua vez, vem ao ser humano pela consciência da finitude, ou seja, quando nos apercebemos de que a morte de todos nós é uma questão de tempo (MORIN, 1973). Segue-se, então, o aparato simbólico. As imagens construídas são elaborações para o enfrentamento dessa inquietude dolorida entre o nascer e o morrer.

O relógio, ao demarcar a passagem do tempo, pode ser um termo demarcador também da consciência da finitude apresentada, com suas pulsações inexoráveis inesgotáveis e sua aparente imortalidade, ditando a fugacidade através das "imagens que passam pela retina", possuindo uma potência dessa noção de angústia existencial, sentida no poema no contato cursivo com a escuridão do lago.

Talvez seja o momento de refletirmos um pouco sobre o título do livro e as relações formadas entre o tempo, a água, os caminhos, os movimentos. Quanto ao título, Clepsidra, o relógio de água.

Clepsidra é um instrumento para medir o tempo, constituído, inicialmente, de dois cones, que se comunicam entre si. Um cone possui água e o outro não. Sendo assim, a passagem da água de um cone a outro demonstra a passagem do tempo. Há também outras formas de construir uma Clepsidra, seguindo o mesmo princípio. 


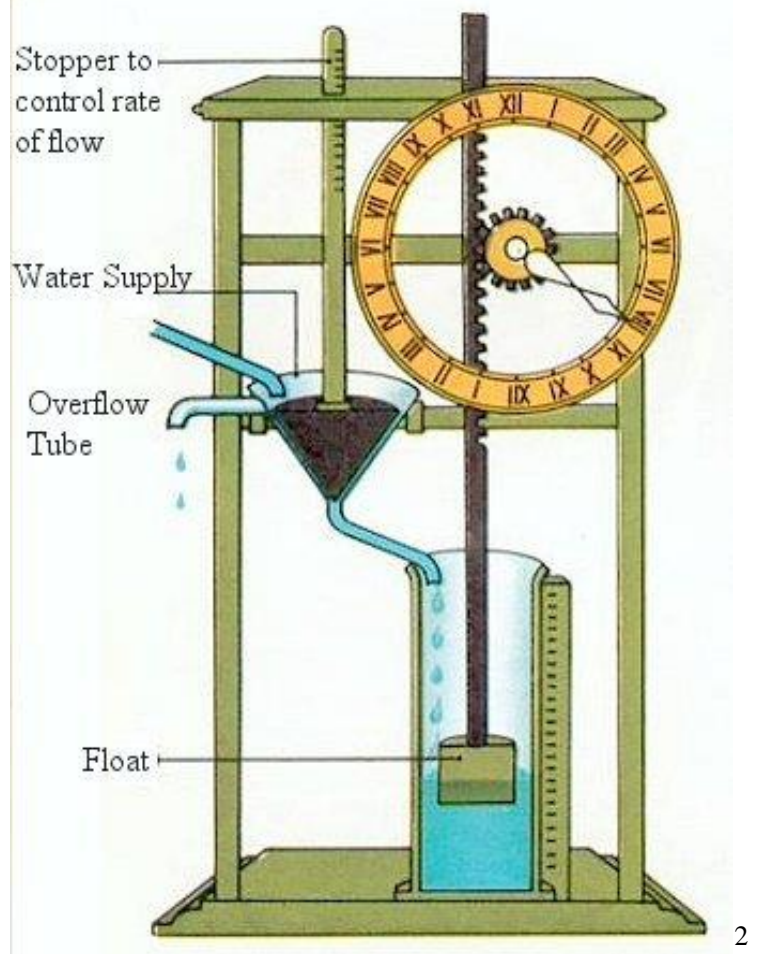

No livro e no poema, Clepsidra ( $\kappa \lambda \varepsilon \psi v ́ \delta \rho \alpha)$, água (v́ $\delta \rho \alpha)$ furtada ( $\kappa \lambda \varepsilon \psi)$, é o tempo em si. Sua transcorrência nos vislumbra que, para enxergarmo-lo ou tocá-lo, precisamos nos perder, sermos furtados pelas imagens, paredes labirínticas das nossas sensações, ao tocarmos com os olhos e ouvidos a densidade mais profunda do mundo. A água furtada dos olhos deixa os olhos secos ("aridez de sucessivos desertos"). A água furtada é a passagem do tempo, a angústia do tempo.

\footnotetext{
${ }^{2}$ Disponível em http://clipart-library.com/clipart/1585307.htm
} 


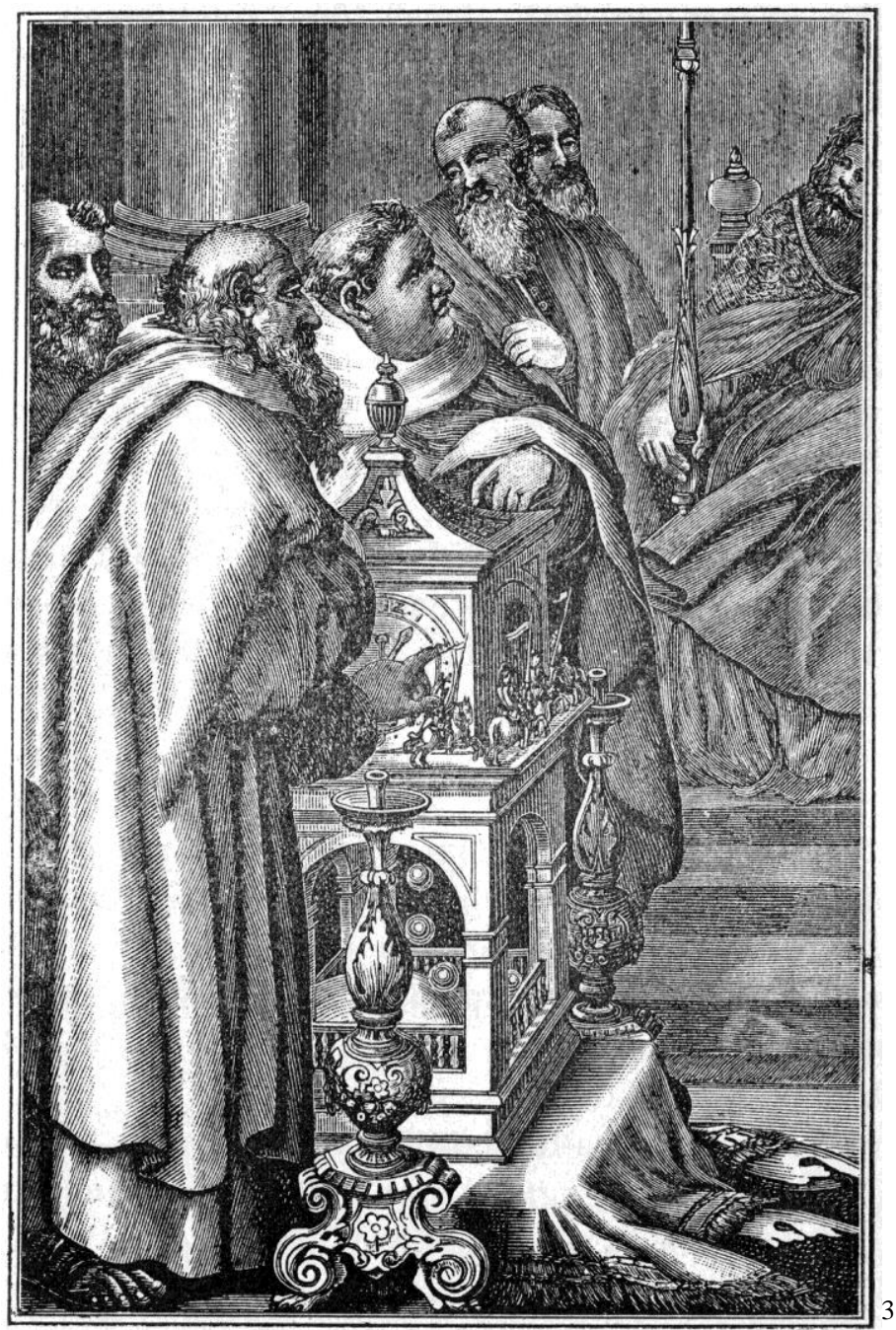

O tempo escoa, como o rio, como os sons dos versos. Embora o homem procure controlar esse escoamento do tempo e da água com canaletas, arquedutos, tubulações e mesmo até relógios, eles todos seguem seus caminhos imprecisos e esvaecidos. Mesmo numa grande quantidade de água, há também caminhos esvaecidos e labirínticos, como o mar.

Em relação ao MAR, teríamos um posicionamento em CHEVALIER:

MAR

Símbolo da dinâmica da vida. Tudo sai do mar e tudo retorna a ele: lugar dos nascimentos, das transformações e dos renascimentos. Águas em movimento, o mar simboliza um estado transitório entre as possibilidades ainda informes e as realidades configuradas, uma situação de ambivalência, que é a de

\footnotetext{
${ }^{3}$ Disponível em:

https://pt.wikipedia.org/wiki/Clepsidra\#/media/Ficheiro:Wasseruhr_Harun_al_Raschid.jpg Clepsidra presenteada a Carlos Magno pelo Califa Harune Arraxide.
} 
incerteza, de dúvida, de indecisão, e que pode se concluir bem ou mal. Vem daí que o mar é ao mesmo tempo a imagem da vida e a imagem da morte. (CHEVALIER, 1993. p.592)

No livro Clepsidra, há também poemas referentes ao mar, como se agisse em torno da matéria água e do que ela suscita no nosso mundo de imagens-encontro. A noção de caminho, de relação morte-vida, de movimento.

O pescador penetra sutilmente no Mar e é também penetrado por ele quando recebe dele a constatação do movimento das ondas, da transitoriedade da vida pulsando em seus pensamentos. Ele e o Mar passam também a ser uma pessoa só. (GIRALDES, 2016, p.49)

Caro leitor, imagine que você esteja no meio do oceano, observando-o e observando-se enquanto o observa. Parece-nos que somos absorvidos pelo ente que tentamos penetrar. Há um poema de Vinícius de Moraes (Ariana, A Mulher), em que essa sensação é até explicitada pelo poeta: (MORAES, 2011, p.69).

Quando, aquela noite, na sala deserta daquela casa cheia na montanha em [torno

O tempo convergiu para a morte e houve uma cessação estranha seguida de [um debruçar do instante para outro instante

Ante o meu olhar absorto o relógio avançou e foi como se eu tivesse me [identificado a ele e estivesse batendo soturnamente a Meia-Noite

[...]

Senti que a Natureza tinha entrado invisivelmente através das paredes e se [plantara aos meus olhos em toda a sua fixidez noturna

E que eu estava no meio dela e à minha volta havia árvores dormindo e [flores desacordadas pela treva.

Quando caí no ventre quente de uma campina de vegetação úmida e sobre a [qual afundei minha carne. (MORAES, 2011, p.69)

Muito interessante a intertextualidade temática entre o poema de Vinícius de Moraes e o poema "Imagens que passais pela retina" de Camilo Pessanha: nos dois poemas, há a imagem do "deserto" no meio da natureza (árvores, flores e juncais), há a noção da passagem do tempo (angústia existencial já comentada e o contato "instante a instante" com a morte), há o relógio (relógio de água do livro Clepsidra e a referência direta em “Ariana, A Mulher”) e, por fim, há a natureza penetrando nos olhos dos poetas e os poetas a, potencialmente, serem absorvidos 
pelo ventre da vegetação e pelos juncos, uma síntese a demonstrar o Regime Noturno da Imagem.

As diferenças entre os dois poemas encontram-se, num primeiro momento, nas figuras da água ("Imagens que passais pela retina") em contraposição às figuras da terra ("Ariana, A Mulher"), e, num segundo momento, na queda na terra (“Ariana, A Mulher”) e na angústia da não absorção do lago escuro ("Imagens que passais pela retina").

Retomando a noção de absorvermos e sermos absorvidos pelo mesmo ente natural, vamos, então, agora, perdermo-nos por outro ente infinito (o mar), naveguemos por outro poema:

\section{SÃO GABRIEL}

Inútil! Calmaria. Já colheram

As velas. As bandeiras sossegaram,

Que tão altas nos topes tremularam,

- Gaivotas que a voar desfaleceram.

Pararam de remar! Emudeceram!

(Velhos ritmos que as ondas embalaram)

Que cilada que os ventos nos armaram!

A que foi que tão longe nos trouxeram?

São Gabriel, arcanjo tutelar,

Vem outra vez abençoar o mar,

Vem-nos guiar sobre a planície azul.

Vem-nos levar à conquista final

Da luz, do Bem, doce clarão irreal.

Olhai! Parece o Cruzeiro do Sul!

(PESSANHA, 1989, p.41)

Se seguirmos o fio de água (fio de Ariadne) podemos chegar a uma grande quantidade de água. De lá, seguem os vários caminhos invisíveis dentro do próprio mar. E o próprio mar pode silenciar-se, sem ventos, sem ondas. No poema "São Gabriel", sentimos a ausência de som e de ar. A voz do poeta contrapõe-se ao silêncio, uma oração. Há aqui a noção de 
desencanto ao nos sentirmos perdidos, sem caminhos, quando não mais há os caminhos invisíveis a que chamamos "ventos" e correntes marítimas.

Essa noção do estar-se perdido no meio da água, sem ventos, remete-se a algumas situações literárias:

Se partires um dia rumo a Ítaca,

faz votos de que o caminho seja longo,

repleto de aventuras, repleto de saber.

$[\ldots]$

Tem todo o tempo Ítaca na mente.

Estás predestinado a ali chegar.

Mas não apresses a viagem nunca.

Melhor muitos anos levares de jornada

e fundeares na ilha velho enfim,

rico de quanto ganhaste no caminho,

sem esperar riquezas que Ítaca te desse.

Uma bela viagem deu-te Ítaca.

Sem ela não te ponhas a caminho.

Mais do que isso não lhe cumpre dar-te.

Ítaca não te iludiu, se a achas pobre.

Tu te tornaste sábio, um homem de experiência,

e agora sabes o que significam Ítacas.

(KAVÁFIS, 2006, p.146)

A interpretação de KAVÁFIS valoriza a ideia do estar-se perdido no mar em direção à Ítaca e todas as riquezas que o caminho pode dar. A jornada de Odisseu: 


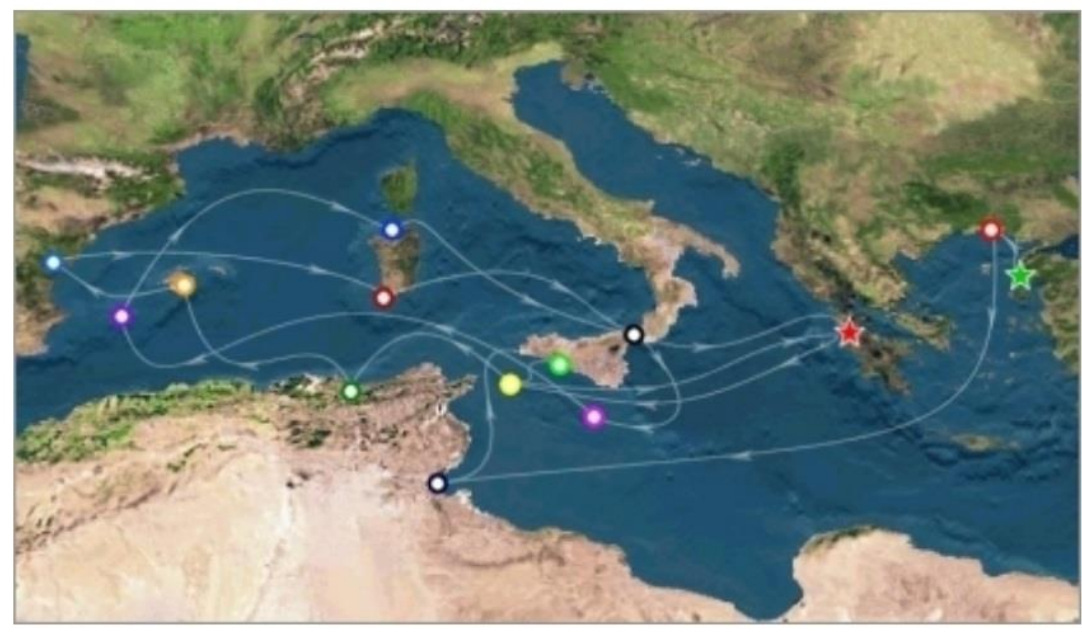

4

Odisseu viajou por todos os caminhos acima esboçados na figura apresentada, pelo mar, com suas idas e vindas, buscando retornar à ilha de Ítaca, à sua casa onírica, ao seu passado, a si mesmo.

A casa onírica é um tema mais profundo que a casa natal. Corresponde a uma necessidade mais remota. Se a casa natal põe em nós tais fundações, é porque responde a inspirações inconscientes mais profundas - mais íntimas - que o simples cuidado de proteção. (BACHELARD, 2003, p.77)

A casa da terra natal está alicerçada na casa onírica. Na casa onírica está o infinito, nossos devaneios mais íntimos. Como sugere Mia Couto: “A casa da infância é como um rosto de mãe: contemplamo-lo como se existisse antes de haver o Tempo" (COUTO, 2011. P.68).

Nosso espaço mais profundo, a busca da nova casa que seja também a casa de nossos sonhos, onde possamos ser o que queremos ou encontrar o que desejamos, perpassa também em nossa história mais longínqua: espaço e tempo se entrelaçam. Nossa memória, devaneando, procura nosso corpo, que toca no espaço também nos procurando em nossa memória. Encontramo-nos, dessa forma, no contínuo trânsito entre a casa perfeita do passado e a casa perfeita do futuro, permeando-nos tudo isso pelos espaços que chegam, sempre em parte, do que somos e do que desejamos ser. (GIRALDES, 2016, p. 58).

\footnotetext{
${ }^{4}$ Disponível em - http://www.classics.upenn.edu/myth/php/homer/index.php?page=odymap. A jornada de Odisseu.
} 
A leitura dos poemas, com a alegria da imaginação, vislumbra os ecos da casa onírica da infância, o grande aposento, o quartinho; mas também pode vislumbrar uma casa do futuro, similar à casa natal.

Talvez seja bom guardarmos alguns sonhos para uma casa que habitaremos mais tarde, sempre mais tarde, tão tarde que não teremos tempo para construíla. Uma casa que fosse "final", simétrica à casa "natal", prepararia pensamentos e não mais sonhos, pensamentos graves, pensamentos tristes. Mais vale viver no provisório que no definitivo. (BACHELARD, 2008, p.74)

Quanto ao mar propriamente dito e suas implicações no estar-se perdido, a presença dos deuses segue como referência também às imagens: Agamêmnon, em Ifigênia em Áulis ${ }^{5}$, precisa sacrificar a própria filha para que Ártemis cesse a calmaria dos ventos que impede os gregos de chegarem a Tróia; Odisseu se perde no retorno à Ítaca por conta de Posídon (HOMERO, 2011); nos Lusíadas, quem impede os ventos é Baco quem os ajuda é Vênus (CAMÕES, 1974).

Fernando Pessoa vê o deus cristão como fomentador do quinto império marítimo em Mensagem. Há em Mensagem a questão dos portugueses no mar e sua busca por sua identidade como povo ultramarino, retomando imagens desde Homero até Camilo Pessanha: a interpelação dos deuses, a predestinação sagrada em encontrar-se como povo através das conquistas marítimas advindas dos caminhos descobertos pelo labirinto do mar, a imersão no infinito da natureza como infinito de si mesmo no próprio destino.

Deus quer, o homem sonha, a obra nasce.

Deus quis que a terra fosse toda uma,

Que o mar unisse, já não separasse.

Sagrou-te, e foste desvendando a espuma,

E orla branca foi de ilha em continente,

Clareou, correndo, até ao fim do mundo,

E viu-se a terra inteira, de repente,

Surgir, redonda, do azul profundo.

\footnotetext{
${ }^{5}$ Estudo de TORRANO (2014)
} 
Quem te sagrou, creou-te portuguez.

Do mar e nós em ti nos deu signal.

Cumpriu-se o Mar, e o Império se desfez.

Senhor, falta cumprir-se Portugal!

(PESSOA, 2010, P.61)

A unidade de tudo pelo sagrado, unificada pelo que separa. A obra tocada pelo mar e seus caminhos, a noção de que estar no meio do mar perdido, quando amparado pelos deuses, é estar no meio de um caminho de experiências e encontros. A evocação, as orações, o viés simbólico em contato com a matéria (água) na imersão do homem no cosmos que o cerca (Ariana, a mulher). Enfim, no estar-se perdido, permitir-se que o fio dos deuses nos navegue, confiar de olhos fechados nas correntes da vida, singrar-se pelo desconhecido e pelas sensações que ele nos traz:

Não sou eu quem me navega

Quem me navega é o mar

É ele quem me carrega

Como nem fosse levar.

$[\ldots]$

A onda que me carrega

Ela mesma é quem me traz.

(VIOLA, 1996)

Transpondo-se a noção de labirinto para as questões acadêmicas e "científicas", notamos o quanto, numa análise mais profunda e metódica deparamo-nos como um navegante evocando São Gabriel:

As análises tradicionais colocam-nos em um labirinto de espelhos, onde tentamos descobrir o significado absoluto das imagens que vemos, sem compreender que muda o significado delas quando muda a pessoa que entra no labirinto e, ao percebermos as nossas diferenças, em vez de humildemente constatarmos o óbvio, ficamos trocando de método, trocando de espelho, trocando a cor do labirinto à cata de alguma realidade igual para todos. (GIRALDES, 2011, p.23) 
O labirinto parece não se encontrar no objeto em si ou no sujeito que o analisa, mas na relação, relação esta instaurada no movimento contínuo, pulsar das ondas, fluxo do fio de água:

O que expressará as perspectivas do estar perdido? Será o anel, ou a felicidade, ou a moralidade? E quanta consistência psíquica quando é o anel $\underline{\mathbf{e}}$ a felicidade e a moralidade! Assim, também, no labirinto, o ser é ao mesmo tempo sujeito e objeto conglomerados no estar perdido. (BACHELARD, 2003, p.163)

Dentro das várias significações que o labirinto pode trazer ou suscitar, apresentamos aqui alguns fios tênues que, por incrível que pareça, poderão servir de alicerces para uma aproximação com mundo das imagens. Urgem transposições de discursos, de olhares, de toques nessa penetração do desconhecido a que universo, o cosmos, propõe-nos. Aqui, neste ponto do texto, não se trata de uma chegada, de um fim, mas sim, de um fio que possibilitará olhares, escutares e toques. Tal como João e Maria, perdidos na floresta, temos as migalhas, talvez o mais importante:

Na minha cidade tem poetas, poetas

Que chegam sem tambores nem trombetas

Trombetas e sempre aparecem quando

Menos aguardados, guardados, guardados

Entre livros e sapatos, em baús empoeirados

Saem de recônditos lugares, nos ares, nos ares

Onde vivem com seus pares, seus pares

Seus pares e convivem com fantasmas

Multicores de cores, de cores

Que te pintam as olheiras

$\mathrm{E}$ te pedem que não chores

Suas ilusões são repartidas, partidas

Partidas entre mortos e feridas, feridas

Feridas mas resistem com palavras

Confundidas, fundidas, fundidas

Ao seu triste passo lento

Pelas ruas e avenidas.

Não desejam glorias nem medalhas, medalhas 
Medalhas, se contentam

Com migalhas, migalhas, migalhas

De canções e brincadeiras com seus

Versos dispersos, dispersos

Obcecados pela busca de tesouros submersos.

(SANDRONI e MASLIAH, 1989)

\section{Referências}

BACHElARD, G. A Terra e os Devaneios do Repouso. São Paulo: Martins Fontes, 2003. Tradução: Paulo Neves.

A Poética do Espaço. São Paulo: Martins Fontes, 2008. Tradução Antônio de Pádua Danesi. 242p.

A Água e os Sonhos. São Paulo: Martins Fontes, 2002. Tradução Antônio de Pádua Danesi. 202p.

CAMÕES. L. de. Os Lusíadas. Rio de Janeiro: Grifo, 1974. 343p. Notas de Evanildo Bechara e Segismundo Spina.

CICERO, A. Guardar. In: Guardar. Rio de Janeiro: Record, 1996. 101p.

COUTO, M. O outro pé da sereia. São Paulo: Companhia das Letras, 2011.

CHEvalier, J. e GHEERBRAnT, A. Dicionário de Símbolos. Rio de Janeiro: José Olympio, 1993. Tradução Vera da Costa e Silva. 996p.

DURAND, G.. As Estruturas Antropológicas do Imaginário. São Paulo: Martins Fontes, 2002. Tradução: Hélder Godinho. 551p.

FELICIO, V. L. G. A imaginação simbólica. São Paulo: EDUSP, 1994.140p.

FERREIRA-SANTOS, M. e ALMEIDA, R. de. Aproximações ao imaginário - bússola de investigação poética. São Paulo: Képos, 2012.

GIRALDES, A.R. Aspectos da Formação da Identidade do Migrante: pedagogia da Escolha, Imaginário e Sociedade. São Paulo, 2016 (Tese de Doutorado em Educação Departamento de Cultura e Organização da Faculdade de Educação da Universidade de São Paulo. 118p. 
Mestres e Heróis: Mitohermenêutica da Formação de Identidade de

Professores. São Paulo, 2011 (Dissertação de Mestrado em Educação - Departamento de Cultura e Organização da Faculdade de Educação da Universidade de São Paulo. 132p.

HOMERO. Odisseia. São Paulo: Companhia das Letras, 2011. 574p. Tradução de Frederico Lourenço.

JUNG, C. G.. A importância dos sonhos. In: O Homem e seus Símbolos. Tradução. Maria Lúcia Pinho. Rio de Janeiro: Nova Fronteira, 1964. 316p.

KAVÁFIS, K. Ítaca. In: Poemas. Rio de Janeiro: José Olympio, 2006. Tradução de José Paulo Paes. 234p.

MERLEAU-PONTY, M.. O entrelaçamento - o quiasma. In: O visível e o invisível. São Paulo: Perspectiva, 1992. 250p.

MORAES, V. de. Ariana, a mulher. In: Antologia Poética. São Paulo: Companhia das Letras, 2011. 325p.

MORIN, E. O paradigma perdido: a natureza humana. Lisboa: Europa-América, 1973. $202 p$.

PESSOA, F. Mensagem. Lisboa: Babel, 2010. 113p.

PESSANHA, C.. Clepsidra. São Paulo: Núcleo, 1989. 80p.

SANDRONI e MASLIAH. Guardanapos de Papel. In: Clara Sandroni. Rio de Janeiro: Kuarup, 1989.

TORRANO, J. A. A. A noção mítica de justiça nas relações de poder na tragédia Ifigência em Áulida de Eurípides. In: Let. Cláss., São Paulo, v. 18, n.2 , p. 16-24, 2014.

VIOLA, P. da. Timoneiro. In: Bebadosamba. Rio de janeiro: Sony, 1996.

ROSA, J. G. Grande Sertão: Veredas. Rio de Janeiro: Nova Fronteira, 2001. 560p.

VALERY, P. Existência do Simbolismo. In: Variedades. São Paulo: Iluminuras, 2011. 238p.

Artigo recebido em: 13.10.2019

Artigo aceito para publicar em: 02.12.2019 